\title{
Editorial: Melt Water Retention Processes in Snow and Firn on Ice Sheets and Glaciers: Observations and Modeling
}

\author{
Horst Machguth $^{1 *}$, Jason E. Box ${ }^{2}$, Robert S. Fausto ${ }^{2}$ and William Tad Pfeffer ${ }^{3}$ \\ ${ }^{1}$ Department of Geosciences, University of Fribourg, Fribourg, Switzerland, ${ }^{2}$ Geological Survey of Denmark and Greenland \\ GEUS, København, Denmark, ${ }^{3}$ Cooperative Institute for Research in Environmental Sciences, University of Colorado, \\ Boulder, CO, United States
}

Keywords: ice sheets, glaciers, retention, percolation, refreezing, cold content, surface mass balance

\section{Editorial on the Research Topic}

Melt Water Retention Processes in Snow and Firn on Ice Sheets and Glaciers: Observations and Modeling

\section{INTRODUCTION}

OPEN ACCESS

Edited and reviewed by: Regine Hock,

University of Alaska Fairbanks, United States

*Correspondence: Horst Machguth

horst.machguth@unifr.ch

Specialty section

This article was submitted to

Cryospheric Sciences,

a section of the journal

Frontiers in Earth Science

Received: 18 June 2018

Accepted: 05 July 2018

Published: 30 July 2018

Citation:

Machguth H, Box JE, Fausto RS and Pfeffer WT (2018) Editorial: Melt Water Retention Processes in Snow and Firn on Ice Sheets and Glaciers: Observations and Modeling.

Front. Earth Sci. 6:105. doi: 10.3389/feart.2018.00105
More than half of Greenland's current annual mass loss is attributed to runoff from surface melt (Enderlin et al., 2014; van den Broeke et al., 2016). While this already suggests that melt plays an important role in Greenland's mass balance, it is worth noting that only slightly more than half of the surface melt runs off in today's climate (Steger et al.). The remaining half of the meltwater produced is retained in firn and snow and does not contribute to runoff. If the fraction of retained meltwater were to decrease, the impact of surface melt on ice sheet mass balance could become much larger. Compared to Greenland, Antarctic surface melt is comparatively very small and has limited direct impact on mass balance. However, a process called hydrofracturing provides even smaller amounts of meltwater with a potentially powerful lever on Antarctic sea level contribution; meltwater that accumulates in crevasses promotes growth of fractures and reduces the stability of Antarctic ice shelves (Kuipers Munneke et al., 2014; Pollard et al., 2015), potentially leading to their detachment. While the break-off of an ice shelf can have a strong impact on the flow of the glaciers feeding the former ice shelf (Mercer, 1978), there are also more subtle ways by which meltwater and meltwater retention in snow and firn influence ice dynamics. The release of latent heat upon refreezing efficiently warms snow or firn while heat conduction and advection expand the warming signal. This effect, termed cryo-hydrological warming (Phillips et al., 2010; Lüthi et al., 2015), raises temperature, associated viscosity and consequently flow velocity of glaciers and ice sheets (Colgan et al., 2015).

This brief review highlights why understanding meltwater retention processes is crucial to anticipate future changes in ice sheets and glaciers in a warming world. The 11 studies of this Frontiers in Earth Sciences Research Topic examine various aspects of meltwater retention in snow and firn. In the following, we separate research progress and challenges into three categories: measuring firn properties, modeling firn structure and meltwater retention, and unraveling the mechanisms associated with the Greenland firn aquifers. 


\section{MEASURING FIRN PROPERTIES}

Measuring the firn meltwater retention process and its influence on land ice hydrology is inherently challenging as the major processes take place at the subsurface in a spatially heterogeneous manner. While a large body of work on snow hydrology exists (e.g., Colbeck, 1972; Hirashima et al., 2014), the firn of glaciers and ice sheets comprises scales and structures not usually identified in seasonal snow, and are produced by multi-year processes also not known from seasonal snow studies. Hence, dedicated measurements of firn hydrology can complement snow studies. Sommers et al. address firn water through their approach of in situ pneumatic measurements of firn permeability. While earlier research (e.g., Albert et al., 1996) focused on dry firn, they studied firn regularly exposed to melt. Sommers et al. adds to an increasing number of innovative in situ measurements of melting firn, such as for example direct observation of percolating meltwater by means of ground penetrating radar (Heilig et al., 2018). Samimi and Marshall examine firn meltwater retention from the perspective of a temperate mountain glacier. Through direct measurement of temperature and water content, they find that temperate snow and firn does not retain meltwater directly, but overnight refreezing of meltwater consumes about $10-15 \%$ of the melt energy available the subsequent day. Samimi and Marshall thus underline the importance of short-term cycles of melt and freezing which even influence mass balance of bare ice areas of the Greenland ice sheet (Smith et al., 2017).

\section{MODELING OF FIRN STRUCTURE AND MELTWATER RETENTION}

Meltwater retention in snow and firn moderates Greenland ice sheet mass loss and global sea level (Pfeffer et al., 1991; Janssens and Huybrechts, 2000). This global impact stands in stark contrast to the small-scale variability of meltwater percolation and retention that manifests itself in the complexity of firn structures (Brown et al., 2011). Modelers generally invoke a concept where vertical percolation is described as either (i) a homogeneously progressing wetting front in isothermal snow and firn at $0^{\circ} \mathrm{C}$, or (ii) heterogeneous flow in advance of a uniform wetting front in a matrix at sub-freezing temperatures. van Pelt et al., Steger et al., and Langen et al. apply firn meltwater models to assess future relevance of retention processes on a synthetic Arctic glacier and to quantify the present-day role of meltwater retention on the Greenland ice sheet. Langen et al. show their model achieving agreement with observed firn stratigraphy and mass balance while Steger et al. conclude that Greenland's snow and firn currently retain $41-46 \%$ of all liquid water (mainly melt but also including rain). All three studies, however, invoke homogeneous percolation and leave the issue of heterogeneous flow as poorly understood. Models of heterogeneous percolation exist (Hirashima et al., 2014; Wever et al., 2016) but they are computationally expensive and validation of model output is challenged by uncertainties of basic input parameters such as fresh-snow density (Steger et al.). These challenges are addressed by Marchenko et al. who suggest a simple empirical parametrization of preferential flow and by Fausto et al. who analyzed a large set of firn and snow data to improve estimates of Greenland snow density.

\section{FIRN AQUIFERS}

In spring 2011 in a little studied region of southeast Greenland, a group of researchers were surprised when their drill emerged from its borehole dripping with water (Forster et al., 2014). Finding liquid water in the firn before the melt season had even started was a surprise and inspired a new Greenland research field in perennial firn aquifers. Model simulations exhibit skill in indicating the location of firn aquifers (Forster et al., 2014; Langen et al.) and indicate that the east Greenland aquifer could be a recent phenomenon that formed following strong melt in summer 2010 (Steger et al.). The hydrology of the aquifers is subject to ongoing research, applying seismic methods to determine aquifer thickness and volume, (Montgomery et al.), or slug testing to measure hydraulic conductivity. (Miller et al.). The amount of water contained in the aquifers remains poorly constrained, but the total estimated area of at least 22,000 $\mathrm{km}^{2}$ (Miège et al., 2016) makes firn aquifers potentially significant contributors to global sea level change. In this context, the findings of Poinar et al. are relevant because they suggest that aquifers infiltrate through the hydrofracturing of crevasses down to the bed, which connect to the ice sheet discharge system.

\section{SYNTHESIS}

The study of meltwater retention has been stimulated by recent discoveries such as the Greenland firn aquifers and studies indicating high importance of surface mass balance in sea level scenarios. To further improve understanding of the processes and their relevance in mass balance of glaciers and ice sheets, Van As et al. performed an expert solicitation to point out major hurdles. The survey responses show that the community identifies research priorities in (i) measuring and modeling the spatial heterogeneity of processes, (ii) assessing the permeability of different types of firn to percolating meltwater, and (iii) in improving surface boundary conditions for modeling. It is promising that the 11 manuscripts of this eBook address all three of the challenges identified by the expert pool.

\section{AUTHOR CONTRIBUTIONS}

HM led the authorship of this article. JB, WP, and RF provided text input.

\section{FUNDING}

This article was partially supported by the Independent Research Fund of Denmark grant FNU 4002-00234. HM is partially supported by the Swiss National Science Foundation grant 200021_169453. 


\section{ACKNOWLEDGMENTS}

We thank all authors and reviewers for their contribution

to the research topic on Melt Water Retention

\section{REFERENCES}

Albert, M. R., Arons, E. M., and Davis, R. E. (1996). "Firn Properties Affecting Gas Exchange at Summit, Greenland: Ventilation Possibilities," in Chemical Exchange Between the Atmosphere and Polar Snow, eds E. W. Wolff and R. C. Bales (Berlin; Heidelberg: Springer), 561-565

Brown, J., Harper, J., Pfeffer, W., Humphrey, N., and Bradford, J. (2011). High resolution study of layering within the percolation and soaked facies of the Greenland ice sheet. Ann. Glaciol. 52, 35-41. doi: 10.3189/172756411799 096286

Colbeck, S. C. (1972). A theory of water percolation in snow. J. Glaciol. 11, 369-385

Colgan, W., Sommers, A., Rajaram, H., Abdalati, W., and Frahm, J. (2015). Considering thermal-viscous collapse of the Greenland ice sheet. Earth's Future 3, 252-267. doi: 10.1002/2015EF000301

Enderlin, E., Howat, I., Jeong, S., Noh, M., van Angelen, J., and van den Broeke, M. (2014). An improved mass budget for the Greenland ice sheet. Geophys. Res. Lett. 41, 866-872. doi: 10.1002/2013gl059010

Forster, R. R., Box, J. E., van den Broeke, M. R., Miège, C., Burgess, E. W., van Angelen, J. H., et al. (2014). Extensive liquid meltwater storage in firn within the Greenland ice sheet. Nat. Geosci. 7, 95-98. doi: 10.1038/ngeo2043

Heilig, A., Eisen, O., MacFerrin, M., Tedesco, M., and Fettweis, X. (2018). Seasonal monitoring of melt and accumulation within the deep percolation zone of the Greenland Ice Sheet and comparison with simulations of regional climate modeling. Cryosphere. 12, 1851-1186. doi: 10.5194/tc-12-1851-2018

Hirashima, H., Yamaguchi, S., and Katsushima, T. (2014). A multi-dimensional water transport model to reproduce preferential flow in the snowpack. Cold Reg. Sci. Technol. 108, 80-90. doi: 10.1016/j.coldregions.2014.09.004

Janssens, I., and Huybrechts, P. (2000). The treatment of meltwater retention in mass-balance parameterisations of the Greenland ice sheet. Ann. Glaciol. 31, 133-140. doi: 10.3189/172756400781819941

Kuipers Munneke, P., Ligtenberg, S. R. M., van den Broeke, M. R., and Vaughan, D. G. (2014). Firn air depletion as a precursor of Antarctic ice-shelf collapse. J. Glaciol. 60, 205-214. doi: 10.3189/2014JoG13J183

Lüthi, M. P., Ryser, C., Andrews, L. C., Catania, G. A., Funk, M., Hawley, R. L., et al. (2015). Heat sources within the Greenland Ice Sheet: dissipation, temperate paleo-firn and cryo-hydrologic warming. Cryosphere 9, 245-253. doi: $10.5194 /$ tc-9-245-2015
Processes in Snow and Firn on Ice Sheets and Glaciers: Observations and Modeling. We also thank the funding agencies that supported the studies presented in this eBook.

Mercer, J. (1978). West Antarctic ice sheet and CO2 greenhouse effect: a threat of disaster. Nature 271, 321-325

Miège, C., Forster, R. R., Brucker, L., Koenig, L. S., Solomon, D. K., Paden, J. D., et al. (2016). Spatial extent and temporal variability of Greenland firn aquifers detected by ground and airborne radars. J. Geophys. Res. 121, 2381-2398. doi: 10.1002/2016JF003869

Pfeffer, W., Meier, M., and Illangasekare, T. H. (1991). Retention of Greenland Runoff by Refreezing: implications for projected future sea level change. J. Geophys. Res. 96, 22117-22124

Phillips, T., Rajaram, H., and Steffen, K. (2010). Cryo-hydrologic warming: a potential mechanism for rapid thermal response of ice sheets. Geophys. Res. Lett. 37:L20503. doi: 10.1029/2010GL044397

Pollard, D., DeConto, R. M., and Alley, R. B. (2015). Potential Antarctic Ice Sheet retreat driven by hydrofracturing and ice cliff failure. Earth Planet. Sci. Lett. 412, 112-121. doi: 10.1016/j.epsl.2014.12.035

Smith, L. C., Yang, K., Pitcher, L. H., Overstreet, B. T., Chu, V. W., Rennermalm, A. K., et al. (2017). Direct measurements of meltwater runoff on the Greenland ice sheet surface. Proc. Natl. Acad. Sci. U.S.A. 114, E10622-E10631. doi: $10.1073 /$ pnas.1707743114

van den Broeke, M., Enderlin, E., Howat, I., Kuipers Munneke, P., Noël, B., van de Berg, W. J., et al. (2016). On the recent contribution of the Greenland ice sheet to sea level change. Cryosphere 10, 1933-1946. doi: 10.5194/tc-10-1933-2016

Wever, N., Würzer, S., Fierz, C., and Lehning, M. (2016). Simulating ice layer formation under the presence of preferential flow in layered snowpacks. Cryosphere 10, 2731-2744. doi: 10.5194/tc-2016-185

Conflict of Interest Statement: The authors declare that the research was conducted in the absence of any commercial or financial relationships that could be construed as a potential conflict of interest.

Copyright (C) 2018 Machguth, Box, Fausto and Pfeffer. This is an open-access article distributed under the terms of the Creative Commons Attribution License (CC BY). The use, distribution or reproduction in other forums is permitted, provided the original author(s) and the copyright owner(s) are credited and that the original publication in this journal is cited, in accordance with accepted academic practice. No use, distribution or reproduction is permitted which does not comply with these terms. 